\title{
PEOPLE OR HORNED OWLS?
}

\author{
A talk to the Prairie Habitat Conference, \\ Saskatoon, April 16, 1975 \\ by J. STAN ROWE*
}

My text is taken from the Board of Inquiry transcript for the proposed strip mining and thermal-electric development, Poplar River Power Project (Vol. 3, p. 50):

Chairman: What expectations of improved quality of life (do you) see in this whole project?

Mr. S.: You mean people or horned owls?

Chairman: I have some greater interest in people than horned owls: I'm not at all interested in the horned owl.

Here, honestly expressed, is a viewpoint from which spring the major problems that bedevil the human race. Posed as a question, expecting a resounding negative response, it asks: "Can anything be as important as us?" It implies that human society exists apart from the world of nature and that "quality of life" pertains entirely to cultural things; to pay cheques and artifacts.

What sane person would be interested in saving horned owls if horned owl living-space can be made to yield consumables and jobs? After all, which is more important, people or horned owls, cereal crops or ducks, herefords or deer, forest products or caribou?

\footnotetext{
*Dept. of Plant Ecology.

University of Saskatchewan.

Saskatoun, Sask
}

Humanity in general has not $y$ grasped the truth that we are eart lings, born out of and sustained dai by its water, air, soil, organism Missing still is a lively awareness th the biosphere, with its myriad ar beautiful natural forms and scul turings, is man's habitat, essential to in many respects, important in most

As an aside but pertinent to $t$ point, the word "habitat" applied humans is commonly taken to me "habitation" - house, communit city. The definition slights the world nature, the ground of man's continu existence. So, next year's world co ference in Vancouver, "Habitat '76 will focus on urban living, and dout less many optimistic proposals will made to assure the future of humani by redesigning our cities!

Hard-headed, "realistic" people accept one reason for preservir animals. If it can be shown that the hunting makes good sport, especially the sport is marketable, then the mer of preservation can at least be argue There is, of course, a long tradition interest in animals large enough to seen down the barrel of a gun (or, the water, large enough to take a lure The tradition reaches its fine flowering in game farms and stocke streams, where animals are raised $f$ ritual killing. Even though the tren today is toward "non-consumptivi uses, toward observing ar photographing wildlife, the focus still on us and our interests. Tr 
people first" proposition that guides ur every action is wrong and angerous.

If changes in attitude are to be lade, it is necessary to understand the istorical-cultural reasons for the conemporary disinterest, disdain and ven fear of the natural world. Such atitudes are learned not inborn. Aparently the Greeks believed that the vorld around them was organic, imortant, sacred, and they peopled it ith various deities. Pan, the all-god, ther of the nymphs, dryads and aiads who inhabited groves and treams, symbolized with his wreath of eaves and his pipes the magic and evelry of life in nature. But omewhere in our later tradition the ense of mystery and sanctity was lost. As D. H. Lawrence pointed out, Pan vith goat's beard and cloven hoof was ransformed into the devil. Nature was demythologized" and the door was pened to the so-called objective iewpoint that separates the observer rom the world. Thus western scienific man can exterminate rare life orms, or carve up the biosphere, with olossal unconcern and no apparent jualms. In a relatively few generations ve have lost our roots with the world hat brought us forth in four billion ears of evolution.

Perhaps the pendulum is swinging ack. Certainly the "let it be", hilosophy is gaining ground. A mere years ago the Saskatchewan public aught the idea that the only way to reserve wild animals (except in zoos) $s$ through preservation of their abitat. The Saskatchewan Wildlife federation has been increasingly efective in promoting this simple basic cological concept. It may be a short tep to the realization that, along with he other coinhabitants, the species lomo sapiens also needs his native abitat preserved. But first a commit- ment of people with insight and belief is needed. Such commitment can only come from those with a love of nature.

You may remember that Aldo Leopold tussled with the problem in several articles called The Land Ethic and The Conservation Ethic. He attempted to provide, by analogy, a reason for care of the land. Ethics, he implies, are adaptive responses of the human race; they have social and survival values. What is accepted as "good" turns out to be the system of beliefs and behaviours that, through long experience, the race has found necessary for its continuation. First came the ethics of individual relationships (e.g., Thou shalt love thy neighbour as thyself), then the ethics of societal relationships (Thou shalt look after the greatest good of the greatest number), and now the first glimmers of the ethics of ecological relationships (Thou shalt protect and preserve the health, permanency and productivity of the earth). While Leopold thought of this last essential ethical step as just evolving, I am inclined to believe that it is already present instinctively in each of us, waiting beneath the surface to be released from the wrong habits and activities imposed by a misguided society.

The beauty of ethics, once the intuitive insight is given, is that it lifts questions of behaviour out of the arena of individual and social gain. An ethical person acts from conviction that what she is doing is right, regardless of whether or not it is profitable. A child who cares for his parents is acknowledging, consciously or not, a dependence on them that cannot be priced. Children of the earth should do as much. Everyone who controls a part of the earth - whether a city plot or a farm - should know the ethical responsibility of protecting and preserving, without being paid. 
When judgements of what actions should be taken are made solely on an economic basis, environment always loses. The reason is that economics is necessarily man-centered, not biosphere-centered. Even the ethical actions that center on individuals and society - what we call "altruism" and "humanitarianism" - are to be viewed with distrust because, unrestrained by earth-care, they have ceased to be adaptive. Strange as it may seem, our conventional man-centered ethics are killing us. To the question "Shall we ruin the earth to feed starving humanity?', the unconventional ecological highest ethic must say "No!"

It follows that there are various frames of reference to which the subject of "habitat" can be related. The narrowest possible view simply looks for space to raise selected animals for human use. Perhaps its ultimate outcome is the licensed angling for carp in artificial ponds on strip-mined lands, bird-watching in the city cemetery, or shooting ducks in a barrel. The broadest possible view looks to preservation of representative parts of the biosphere, with their full complements of land and water forms, plants and animals; the preservation of large complete ecosystems that renew the earth simply by being there and producing clean water, fresh air, and life. This is people habitat as well as animal habitat and, in the long run, I don't see how we can settle for less. Between the two extremes lies a broad spectrum of "habitats", for single or multiple human uses, for simple or complex preservation, for narrow goals or broad.
Most wildlife specialists are i volved in management. Their en ployers would probably be unhappy my thesis were widely champione viz., that habitat in the broadest sen - equivalent to natural area ecological reserves and wilderness should be the center of wildlife $\mathrm{i}$ terest. We must be realistic and co cede that in this unenlightened as society is demanding a good deal les Yet it is important that practitione and professionals should also leaders and set high goals. The publ has a way of catching up quickly whe the time and the ideas are right.

The title phrase "People or Horn Owls?", and all other oppositions the same genre, are really no questions and non-alternatives. H must protect and conserve the natur world, horned owls and all, becau that is the right thing to do, because t earth is sacred, and because any oth course denies our biological ar ecological roots. And, as a fortuna spin-off, because this is the only roa to survival. Given acceptance of such stirring and worthwhile goal, t short-term day-to-day man-center aims of habitat management $c$ : perhaps be seen in their correct pc spective, contributing to but far she of the ideal and the necessary. Wildli managers need to recognize a hie archy of habitat goals, giving leadc ship and support to the primary one even while their bread-and-butter jo require that they attend also to tho that are secondary. 